\title{
CONTRIBUTION OF SMALL-SCALE FARMING AND LOCAL FOOD SUPPLY TO SUSTAINABLE PRODUCTION AND FOOD SECURITY IN NIGERIA - A REVIEW
}

\author{
Oluseyi Olutoyin Olugbire ${ }^{\bowtie}$, Olorunfemi Sunmbo ${ }^{2}$, Titilope Omolara Olarewaju ${ }^{1}$
}

${ }^{1}$ Forestry Research Institute of Nigeria, Nigeria

${ }^{2}$ Royal Agricultural University, United Kingdom

\begin{abstract}
Prior to the year 1970, agriculture was the main source of livelihood and backbone of the Nigerian economy until the discovery of oil drastically decelerated its potential to sustainably maintain food security and generate significant export earnings. Despite its sudden fall in productivity, agriculture still remains the main sector providing the highest employment ( $70 \%$ of the population) for the populace. To tackle these problems, many policies were formulated (from 1960 to 2015) to resuscitate the sector but to no availdue to failure in tailoring suitable policies to engage small-scale farmers and address other socio-economic problems. This paper constitutes an in-depth review of agricultural production and food security in Nigeria with relative importance attributed to local food supply and small-scale farmers. The article analyzes several documents of the Nigerian Government and international organizations, such as the Food and Agricultural Organization, the National Bureau of Statistics (NBS), Department of Agriculture and Rural Development and a number of peer-reviewed journals across various disciplines to provide a balanced interdisciplinary review. The paper concludes that food insecurity is at its peak in Nigeria and urgent attention is required in the agricultural sector to compensate for the unstable food balance in the country. There is a need for the Government to take strong measures against the food deficit situation and to support the development of the primary agriculture sector. The paper proposes viable policies that could involve smallholders, aid transformation and positively restructure the agricultural sector.
\end{abstract}

Keywords: small-scale farmers, agricultural export and imports, food security, agricultural policies, Nigeria

\section{INTRODUCTION}

Common to the evolution of the human race is the transition from agriculture practiced at a small-scale as the main source of livelihood to its reform (agrarian revolution), industrialization, civilization, and other forms of transformation that aided development across the globe. Agriculture piloted the main revenue streams of most countries (responsible for $90 \%$ of all food production in some countries) before diversification into other sectors became an alternative to creating multiple streams of income towards a sustainable economy (UNDP, 2013). Through the agrarian revolution, most of the developed countries today transformed into commercialization which begot international trade as a result of comparative advantage opportunities. On the other hand, the majority of the developing countries remain predominantly inundated with smallholders whose production standard and scale need interventions to filldemand-supply gaps at the local, regional and international level to achieve sustainable production and food security (Wiggins, 2009 and UNDP, 2013).

\section{METHODOLOGY}

The article reveals the agricultural production and food security situation in Nigeria with relative importance

$\bowtie$ Oluseyi Olutoyin Olugbire, Department of Forest Economics and Extension Services, Forestry Research Institute of Nigeria,

Ibadan 5054, Oyo State, Nigeria, e-mail: olugbireolutoyin@gmail.com, https://orcid.org/0000-0002-1922-6961 
attached to local food supply and small-scale farmers. An in-depth desk research and document review from several sources was carried out to reveal information on agricultural production and food security situation in the country. Document sources include: the Food and Agricultural Organization, the National Bureau of Statistics (NBS), Federal Government Ministry, Department and a variety of peer-reviewed journals. Document review covered such areas as the historical background to agricultural production- the pre- and post-independent eras; agricultural imports and exports, agricultural policies and attitude towards small-scale farming, among others.

\section{RESULTS AND DISCUSSION}

\section{Small-scale farming and local food supply in Nigeria prior to independence}

Nigeria as a case study is characterized by a current population of over 200 million people and a land area of over 92 million hectares with 82 million hectares suitable for arable farming (PWC, 2016); however, only 32 million hectares of this land is used for farming, accounting for produce generating $\$ 1.4$ billion export earnings, $24.4 \%$ contribution to GDP at a growth rate of $4.1 \%$ and warranted US\$5.3 billion worth of food import to meet the demand deficit (PWC, 2016 and AGRA, 2017). The aforementioned figures mirror the concerted effort of smallholder farmers ( $80 \%$ of all farmers) who are limited in all forms of resources to catch up with the food demand of the growing population, and the remaining $20 \%$ are corporate farmers who are believed by the government to be the main drivers of food supply (Wada, 2012; Oni, 2011 and FMARD, 2001a). Prior to oil discovery in Nigeria, small-scale farming was the driver for food export and its efficiency anchored on the performance and productivity of small-scale farmers whose production at that time kept pace with local food demand to ensure food security, supply raw materials to the agro-industry, provide a livelihood for more than $70 \%$ of the population and at the same time position the country as one of the largest exporters of palm oil, cocoa, groundnut, rubber, and cotton in the world, thereby generating $62.2 \%$ of foreign exchange earnings and contributing $66.4 \%$ to the nation's GDP in 1965 , which is significantly higher than $4.8 \%$ of total earnings, and $24.4 \%$ of GDP in 2016 (Wada, 2012; PWC, 2016 and Ahungwa et al., 2014). Crops commonly grown by these farmers for local consumption include sorghum, millet, cassava, yam, and maize which eliminated poverty, hunger and food insecurity (Wada, 2012 and Wiggins, 2009). However, Nigeria was not only self-reliant in agricultural production and food security but also booming in the world market as the largest producer of groundnut, palm oil, cotton, and cocoa (Eigege and Cooke, 2016). It was in 1970 that oil production hit a boom in the world market and this attracted a significant proportion of the populace from rural centers (who are two-thirds of the total population) leading to a massive migration to cities in a search for job opportunities in the oil industry. This resulted in a lost passion for farming alongside a rapid population increase (with a growth rate of 3-3,5\%). The government reduced food prices to encourage city residents to stay in urban areas and this disrupted the local food supply as farmers had no incentives to produce or market. Hence, between 1972 and 1980, food production per capita dropped by $30-35 \%$, importation rose by $250 \%$, and production for export disappeared (Igbokwe, 1983).

\section{Agricultural production and food security post-independence; the contribution of small-scale farmers}

Data from Tables 1 and 2 reflects a decrease in agricultural production caused by the massive migration of rural smallholder farmers to the oil trade business. Due to the oil trade effect, imports increased, and exports decreased depriving the country of foreign exchange earnings. Tables 1 and 2 further reveal that export of agricultural commodities decreased and their import increased - import was rising from 2010 up to 2018, and export was falling.

The oil boom of 1960 became the negative turning point for prospects in agriculture as production remarkably began to dwindle. Notably, after independence, much focus was directed towards the oil sector, and policies shaped to support agricultural production were fading away (Teal, 1983 and UNDP, 2013). According to Teal (1983), the growth rate of the output of export crops was $4.7 \%$ pre-independence (1950 to 1957 ) and $7.4 \%$ for the early post-independence (1960 to 1965 ) but it suddenly fell by $17.3 \%$ between 1970 and 1975 . Investment in agriculture began to fall in many areas including research and development, access to improved seed, fertilizers, and rural development. This became evident in the level of importation exceeding that of 
Olugbire, O. O., Sunmbo, O., Olarewaju, T. O. (2021). Contribution of small-scale farming and local food supply to sustainable production and food security in Nigeria - A review. J. Agribus. Rural Dev., 1(59), 91-99. http://dx.doi.org/10.17306/J. JARD.2021.01390

Table 1. Agricultural exports in Nigeria

\begin{tabular}{lrrrrrrrrr}
\hline \multicolumn{1}{c}{ Year } & 2010 & 2011 & 2012 & 2013 & 2014 & 2015 & 2016 & 2017 & 2018 \\
\hline Crops & Quantity in Metric Tons & & & & & & & \\
Rice & 94 & 166 & 0 & 144 & 7 & 85 & 21 & 8 & 7 \\
Wheat & 29 & 272 & 111 & 100 & 3,101 & 7 & 21 & 2 & 2 \\
Maize & 8 & 8 & 8 & 7,530 & 2,000 & 6,185 & 3,185 & 4,000 & 4,770 \\
Soy Bean & 11,000 & 8,000 & 11,400 & 8,800 & 9,000 & 9,000 & 9,000 & 121,758 & 34,587 \\
\hline
\end{tabular}

Source: FAOSTAT, 2020.

Table 2. Agricultural imports in Nigeria

\begin{tabular}{|c|c|c|c|c|c|c|c|c|c|}
\hline Year & 2010 & 2011 & 2012 & 2013 & 2014 & 2015 & 2016 & 2017 & 2018 \\
\hline Crops & \multicolumn{9}{|c|}{ Quantity in Metric Tons } \\
\hline Rice & $1,882,759$ & $2,187,419$ & $2,455,202$ & $2,187,370$ & $1,563,963$ & $1,800,000$ & $1,800,000$ & $1,800,000$ & $1,800,000$ \\
\hline Wheat & $3,971,861$ & $4,039,669$ & $4,067,155$ & $4,358,863$ & $4,603,256$ & $4,391,665$ & $4,240,715$ & $5,629,032$ & $4,810,412$ \\
\hline Maize & 550 & 812 & 1000 & 1,200 & 209,583 & 76,026 & 215,266 & 638,068 & 200,000 \\
\hline Soy Bean & 9 & 9 & 5721 & 12,757 & 71,822 & 111,186 & 70,000 & 70,000 & 42,515 \\
\hline
\end{tabular}

Source: FAOSTAT, 2020.

exportation (UNDP, 2013), as importation accounts for US\$11 billion every year (AGRA, 2017; Eigege and Cooke, 2016). All of this reflects higher food demand from the growing population and decreased contribution of small-scale farmers to agricultural production (Anderson, et al., 2017 and AGRA, 2017) whose challenges range from limited financial and market access, low productivity due to climate change and concentration of aged farmers, poor investment in value chains, exclusion and diversion of private investors to the energy sector, redirection of policies towards the oil sector, the focus of credit facilities on medium- and large-scale farmers with the perception of them as the key players in primary production (Eigege and Cooke, 2016). Access to credit to scale up farm enterprises has become so difficult as only $2 \%$ of all financial institutions lending to farmers are into the agricultural sector (Adam, 2013 and Michael, 2011). The most conspicuous indication of the slow and unavoidable fall of the Nigerian agricultural sector manifested itself in the way in which the north of Nigeria, with farmingas its main livelihood, has descended and remained behind on main economic indicators over the past forty years with many areas being food insecure. Estimates from the 2013 demographic and health survey revealed that $37 \%$ of children under the age of 5 are undersized (stunted), 18\% are wasted and 29\% underweight mostly in the eastern and western part of Northern Nigeria (Eigege and Cooke, 2016). According to IFAD (2012), as reported by the Nigerian Food Security portal, over $70 \%$ of Nigerians live below $\$ 1.25$ (poverty line) per day and $80 \%$ of this population lives in rural areas. The National Bureau of Statistics (NBS) further discussed the severity of food insecurity transcending into poverty and hunger by revealing the increase in the population of people living in absolute poverty from $54.7 \%$ in 2004 to $60.9 \%$ in 2010 . With respect to food availability, tables 1 and 2 demonstrate the trend in the rate of exportation and importation for some consecutive years which mirrors the food deficit status.

\section{Problems associated with market links}

Table 3 below provides a summary of the local food supply together with the potential level of demand in 2016. The table revealed that the local food supply of around 13 commodities decreased, but the import will compensate for the food deficit situations. 
Table 3. Estimates of gaps in Nigerian food demand and local food supply

\begin{tabular}{lccc}
\hline \multicolumn{1}{c}{ Crop } & $\begin{array}{c}\text { Demand } \\
\text { (million tons) }\end{array}$ & $\begin{array}{c}\text { Supply } \\
\text { (million tons) }\end{array}$ & $\begin{array}{c}\text { Source of local } \\
\text { supply }\end{array}$ \\
\hline Rice & 6.3 & 2.3 & \\
Wheat & 4.7 & 0.06 & \\
Maize/corn & 7.5 & 7.0 & \\
Soy Bean & 0.75 & 0.6 & \\
Tomato & 2.2 & 0.8 & Small-scale \\
Yam & 39 & 37 & \\
Oil palm & 8.0 & 4.5 & \\
Cocoa & 3.6 & 0.25 & \\
Cotton & 0.7 & 0.2 & \\
Sorghum & 7.0 & 6.2 & \\
Fish & 2.7 & 0.8 & \\
Milk/dairy & 2.0 & 0.6 & \\
Chicken* & 200 & 140 & \\
\hline
\end{tabular}

*Million birds.

Source: FMARD, 2016.

Apart from primary production, a lot of problems are also linked to supply chains of agricultural products and, for deeper assessment, the focus will be centered on fewer agricultural subsectors such as dairy, fishery, tomatoes, and cassava, as prioritized by the government for agribusiness restructuring. In the case of the dairy industry, a majority of cattle farmers (about 12 million) are small-scale pastoralists $(95 \%$ of total herd size) with indigenous cattle that produces a maximum of 0.5-2 liters of fresh milk per day relative to the 6.6 liters produced daily by other pastoralists in the world. Apparently, commercial dairy farms in Nigeria account for 8 liters of fresh milk production per day, compared to 30 liters produced by other commercial dairy farms in the world (UNDP, 2013 and PWC, 2016). The low productivity posed a major problem in the supply chain of fresh milk as only $3 \%$ of it is still being processed by the leading dairy firm out of an average annual demand of 1.6 million liters (UNDP, 2013 and PWC, 2016). A lot of wastage is evident in the value chain as $80 \%$ of the fresh milk produce is channeled directly to consumers and $15 \%$ to local processors who process the fresh milk into Nunu, Fura, and Wara. The remaining 5\% account for the amount channeled to the collection center for leading dairy firms, of which $3 \%$ is accessible and cannot satisfy the $10 \%$ milk quota to be sourced locally by just one of the leading milk industry enterprises (Friesland Campina) in Nigeria which is obligated by the MoU signed with the state government (PWC, 2016). Other constraints associated with the supply chain include small and disorganized collection centers for fresh milk, processing and marketing as a result of the pastoralist system of farming, lack of access to long-term credit, absence of fresh water, deficiency of clear policy, lack of skills and capacity for proper dairy farm management, (Nigeria..., 2007).

Similar to the constraints in the dairy industry are the challenges facing aquaculture in Nigeria. The industry which predominantly consists of small-scale producers with an annual tonnage of 600,000 metric tons (MT) relative to the annual average 2.6 million MT potential demand acclimatized the country to importation in order to catch up with the demand. Nigeria, therefore, became the largest importer of frozen fish in Africa while the local supply system remains with such issues as deprivation of credit, poor regulation standards, inferior infrastructure facilities, transportation problems, excessive post-harvest losses, a dearth of market information and many more (UNDP, 2013).

\section{Past and current agricultural and food policies in Nigeria. Are small-scale farming and local food supply embraced?}

\section{Agricultural and food policy trend with the corresponding impact on small-scale farming and local food supply}

To date, various agricultural policies have been developed to reposition the agricultural sector in Nigeria depending on the growth and development aspired at that period. The bulk of these policies failed mainly because of the implementation strategies which excluded rural farmers (smallholders) who are the major key players in agricultural production, lack of timelines and benchmarks for project execution with no visible established market. The table below provides a summary of the trends in policy from 1960 to 2020, with their disposition to small-scale farming and local food supply. Cf. annex for the summarized text. 
Olugbire, O. O., Sunmbo, O., Olarewaju, T. O. (2021). Contribution of small-scale farming and local food supply to sustainable production and food security in Nigeria - A review. J. Agribus. Rural Dev., 1(59), 91-99. http://dx.doi.org/10.17306/J. JARD.2021.01390

Table 4. Agricultural and food policy trends 1960-2020

\begin{tabular}{|c|c|c|c|c|}
\hline Year & Policy & Main objective & $\begin{array}{l}\text { Disposition towards small-scale } \\
\text { farming }\end{array}$ & Reference \\
\hline Colonial Era & $\begin{array}{l}\text { Unstated but seems to be } \\
\text { the continuation of British } \\
\text { Agricultural Policy during } \\
\text { colonization }\end{array}$ & Export crops promotion & $\begin{array}{l}\text { Supporting export of crops to cater } \\
\text { for British needs and unfavorable of } \\
\text { small-scale farmers }\end{array}$ & Ibeanu, 2008 \\
\hline $\begin{array}{l}\text { Before Civil } \\
\text { war }\end{array}$ & $\begin{array}{l}\text { National Accelerated Food } \\
\text { Production Programs } \\
\text { (NAFPP) }\end{array}$ & $\begin{array}{l}\text { Targeted to increase domestic production } \\
\text { for local consumption and export earnings } \\
\text { for GDP }\end{array}$ & $\begin{array}{l}\text { Focused on commercial farms to } \\
\text { achieve the goal }\end{array}$ & $\begin{array}{l}\text { Michael and Ibra- } \\
\text { him, } 2003\end{array}$ \\
\hline 1976 & $\begin{array}{l}\text { Operation Feed the Nation } \\
(\mathrm{OFN})\end{array}$ & $\begin{array}{l}\text { Increase National Welfare by reducing } \\
\text { food prices and the level of importation }\end{array}$ & Diversion of loans to non-farmers & Ering et al., 2014 \\
\hline 1980 & $\begin{array}{l}\text { Green Revolution (which } \\
\text { was the same as Operation } \\
\text { Feed the Nation but ran by } \\
\text { a new regime) }\end{array}$ & $\begin{array}{l}\text { Improve agricultural productivity by } \\
\text { Increasing domestic production for local } \\
\text { consumption and improving on export } \\
\text { crops through technology adoption }\end{array}$ & $\begin{array}{l}\text { Loans were diverted from small- } \\
\text { scale farmers to larger-scale farmers }\end{array}$ & \\
\hline 1983 & Back to Land & Self-sufficiency in food production & $\begin{array}{l}\text { This supported small-scale farming } \\
\text { but failed shortly due to insufficient } \\
\text { input and technology deficiencies }\end{array}$ & \\
\hline 1985 & $\begin{array}{l}\text { Directorate for Foods, } \\
\text { Roads And Rural Infra- } \\
\text { structure (DFRRI) }\end{array}$ & $\begin{array}{l}\text { Reducing rural-urban migration and } \\
\text { poverty }\end{array}$ & $\begin{array}{l}\text { Inconsistency in policy and inad- } \\
\text { equate involvement of rural farmers. }\end{array}$ & Onah, 2006 \\
\hline 1999 & $\begin{array}{l}\text { Commercial Agricul- } \\
\text { tural Development Program } \\
\text { (CADP) }\end{array}$ & $\begin{array}{l}\text { Developing the tripod of Production, } \\
\text { Processing and Storage }\end{array}$ & $\begin{array}{l}\text { This involved small-scale farming } \\
\text { by introducing Guaranteed Mini- } \\
\text { mum Price to stabilize market prices } \\
\text { for smallholders, the innovation of } \\
\text { farmers' market to create market ac- } \\
\text { cess, the establishment of agro-input } \\
\text { centers for smallholders, etc. Impact } \\
\text { not stated but obviously, it failed to } \\
\text { solve the problems of the farmers as } \\
\text { a new policy was developed in } 2011\end{array}$ & Kolawole, 2009 \\
\hline 2001 & $\begin{array}{l}\text { The New Nigeria Agricul- } \\
\text { tural Policy }\end{array}$ & $\begin{array}{l}\text { Similar to the preceding policies, some of } \\
\text { the objectives are } \\
\text { - Self-sufficiency in basic food supply and } \\
\text { attainment of food security by introduc- } \\
\text { ing improved seeds and recognition of } \\
\text { the potentials of small-scale farmers as } \\
\text { the main food producers in the country } \\
\text { - Creating enabling-environment (macro- } \\
\text { economic ) policies for the policy to } \\
\text { thrive }\end{array}$ & $\begin{array}{l}\text { An entire part of the policy was in } \\
\text { favor of smallholders. However, } \\
\text { there was no literature capturing the } \\
\text { evaluation after the expiration of the } \\
\text { policy. } \\
\text { The introduction of the ATA shows } \\
\text { that the problems still exist and there } \\
\text { is still much more to be achieved }\end{array}$ & FMARD, 2001a \\
\hline 2002 & $\begin{array}{l}\text { National Programme for } \\
\text { Food Security }\end{array}$ & $\begin{array}{l}\text { The broad objective of the program was } \\
\text { to increase food production and eliminate } \\
\text { rural poverty. Specific objectives include: } \\
\text { Assisting farmers in increasing their } \\
\text { output, productivity and income; strength- } \\
\text { ening the effectiveness of research and } \\
\text { extension service training and educating } \\
\text { farmers on farm management for effective } \\
\text { utilization of resources }\end{array}$ & $\begin{array}{l}\text { The inability of the majority of the } \\
\text { beneficiaries to repay their loan on } \\
\text { time, complexity and incompatibility } \\
\text { of innovation, and difficulty in inte- } \\
\text { grating technology into the existing } \\
\text { production system. }\end{array}$ & FMARD, 2001b \\
\hline $\begin{array}{l}2011-2015 / \\
2015-2020\end{array}$ & $\begin{array}{l}\text { Agricultural Transformation } \\
\text { Agenda (ATA) }\end{array}$ & $\begin{array}{l}\text { To address the problems untackled by past } \\
\text { policies }\end{array}$ & $\begin{array}{l}\text { An entire part of the policy was in } \\
\text { favor of smallholders }\end{array}$ & FMARD, 2016 \\
\hline
\end{tabular}

Source: Ering et al., 2014 and Ibietan, 2011. 
Olugbire, O. O., Sunmbo, O., Olarewaju, T. O. (2021). Contribution of small-scale farming and local food supply to sustainable production and food security in Nigeria - A review. J. Agribus. Rural Dev., 1(59), 91-99. http://dx.doi.org/10.17306/J. JARD.2021.01390

\section{Most recent agriculture and food policy with impact on small-scale farming and local food supply}

After several ups and downs which led to the abandonment of the sector, the Federal Government of Nigeria in 2011 developed the "Agricultural Transformation Agenda" (ATA) policy, to address the problems untackled by past policies. Despite the restructuring objectives of the ATA policies, the level of importation is still high and food insecurity is still at its peak. Likewise, exportation is nothing to compare with in relation to benchmarking elements. The main problem that remains is the lack of lending to farmers from financial institutions as well as an extremely high level of importation. Obviously, agriculture has not received substantial support from the government because Nigeria has failed to achieve the $10 \%$ minimum budgetary allocation to agriculture following the Mozambique Maputo declaration of 2014. This evidently insinuates a lack of support for small-scale agriculture, since it is the driver of the sector. Tables 5 and
6 below summarize the achievements and shortcomings that accompany the execution of ATA.

\section{Current agricultural and food policy in Nigeria. Agricultural Promotion Policy 2016-2020}

Limitations arising after the implementation of the Agricultural Transformation Agenda (ATA) led to the development of another policy entitled Agricultural Promotion Policy 2016-2020. This policy aims to bring an end to the insufficiencies in local food production for domestic consumption and also sustainably stabilize the production of export crops to generate good export earnings.

In achieving these, policies aimed to:

- Ebrace public-private partnership as the key means to drive the sector,

- Commercialize agriculture through technology transfer, financial input, supply chains and market linkages that directly support small-scale farmers.

Table 5. The achievements of the Agricultural Transformation Agenda

\begin{tabular}{|c|c|}
\hline Area & Examples of achievements \\
\hline Input Supply & $\begin{array}{l}\text { o Set up of the Growth Enhancement Scheme to register smallholder farmers and provide target input subsidies } \\
\text { (E-wallet) } \\
\text { - GES repository accounts for } 10.5 \text { million farmers (the veracity of data sources is unsure) } \\
\text { - Targeted means-tested subsidies provided to approximately } 12 \text { to } 14 \text { million farmers between } 2011 \text { and } 2014 \\
\text { o Farmers gaining better (subsidized) access to inputs such as fertilizers and seeds }\end{array}$ \\
\hline Financing & $\begin{array}{l}\text { o Development of Nigeria Incentive-based Risk Sharing System for Agricultural Lending (NIRSAL) through } \\
\text { a partnership with Central Bank of Nigeria and other Bank Committees } \\
\text { o Revitalization and partial recapitalization of the Bank of Agriculture (BOA) } \\
\text { o Engagement with Commercial banks to finance GES and boost lending to agriculture from approximately } 1 \% \text { to } \\
6 \% \text { of all formal credit by } 2015 \\
\text { o Creation of special funds to support farmers, e.g. the N10 billion Cassava fund and the FAFIN/KFW facility of } \\
\$ 35 \text { million }\end{array}$ \\
\hline $\begin{array}{l}\text { Infrastructure } \\
\text { and Logistics }\end{array}$ & $\begin{array}{l}\text { o Designation of a staple food crop processing zone; } 1^{\text {st }} \text { site in Kogi for Cassava Production remains under } \\
\text { development } \\
\text { o Franchise of federal warehouses and storage assets }\end{array}$ \\
\hline Production & $\begin{array}{l}\text { o Introduction of new higher-yielding crop varieties e.g. cocoa, rice (Faro } 42 \text { and } 44 \text { ) } \\
\text { o Domestic food production rising by an incremental } 20.1 \mathrm{M} \text { tons (claims not evidence-based) } \\
\text { - Rice paddy production rising by an estimated } 2.0-2.5 \text { million tons } \\
\text { o Creation of the Federal Department of Agricultural Extension }\end{array}$ \\
\hline Market Access & o Re-establishment of marketing boards for selected commodities, e.g. Cocoa Marketing Corporation \\
\hline Others & o Reform of the Agricultural Research Network (ARCN) \\
\hline
\end{tabular}

Source: FMARD, 2016. 
Olugbire, O. O., Sunmbo, O., Olarewaju, T. O. (2021). Contribution of small-scale farming and local food supply to sustainable production and food security in Nigeria - A review. J. Agribus. Rural Dev., 1(59), 91-99. http://dx.doi.org/10.17306/J. JARD.2021.01390

Table 6. The shortcomings of the Agricultural Transformation Agenda

\begin{tabular}{ll}
\hline \multicolumn{1}{c}{ Area } & \multicolumn{1}{c}{ Examples of shortcomings } \\
\hline Input Supply & o GES's limited focus and exit strategy set aside, with material implications for the Ministry's budget, resulting in \\
& a sharp rise in indebtedness to banks. The system has many leakages from farmer registration and data capture to \\
& supply and distribution mechanism \\
& o Insufficient access to improved varieties of seeds e.g. still a 300,000 MT gap between the demand and supply of \\
& seeds
\end{tabular}

Source: FMARD, 2016.

- Tailor policy to support the development of social responsibility in agriculture as regards food security.

- Focus the policy on developing enterprise across commodity value chains.

- Stimulate market stabilization by linking producers to off-takers.

- Facilitate inclusiveness of all stakeholders, including farmers' associations, government parastatals, cooperatives and NGOs.

- Direct policy to eradicate corruption in reducing funds and diversion of credit away from the vulnerable and linking agriculture with other sectors

Therefore, the FMARD decided to prioritize some agricultural produce (rice, wheat, maize, sugar, dairy milk, soybean, poultry, horticulture (vegetables and fruits) and aquaculture) which were believed to drive food security within the country. And for export, cocoa, cashew, cowpea, cassava, Ginger, sesame, palm oil and
Yam were prioritized. The implementation of these policies is still at an early stage and if strictly followed, it should include small-scale farmers.

\section{CONCLUSION AND RECOMMENDATIONS}

In conclusion, food insecurity in Nigeria is still at its peak. Very urgent attention is required to compensate for the unstable situation in the country. The government has to take radical measures aimed at the development of the primary agriculture sector.

\section{Proposed agricultural policy development to support small-scale farming and local food supply}

Examples from the in-depth review of agricultural production and policy trends in Nigeria vividly reveal the 
role and impacts of smallholder farmers in driving Nigeria to be self-sufficient in food production both for local consumption and exportation. Likewise, they reflect the fall in food production as focus shifted away from these farmers to support the oil trade. This resulted basically in low food production for domestic consumption, high dependency on food importation and low exportation as the main challenges. Ever since then, several policies have emerged to address these same problems so as to reposition agriculture back to the state in which it was before it dwindled but were never successful. However, in order to come out of these problems, suitable policies must be developed to (1) address the switch from prioritizing petroleum over agriculture (which is a means to overcome the underpinning problem and maintain a balanced diversified economy) (2) correct the failures of past agricultural policies and build on their successes as well. These two policies will be expressly split into simpler policies for implementation and also for complementing the current Agricultural Promotion Policy.

- Policies should be precise in recognizing and acknowledging small-scale farmers as the main land users and drivers of the food production sector, in order to regain food self-sufficiency for local consumption and exportation, acknowledging the fact that they are the majority among the farming population.

- Policy should address the development of a mechanism to distinguish the targeted farmers from other farmers for efficient intervention support.

- Restructuring of land administration system to include smallholders in formal ownership so as to enable their use of land as a collateral for loans.

- Policy to support easy access to inputs and the use of mechanized farming, precision farming (soil testing, suitable fertilizer use, adoption of improved planting materials, ICT), acquisition of improved breeds of animals especially in dairy production through government intervention support.

- Policies should be strictly addressed towards the consistent implementation of the CAADP target of $10 \%$ release of total expenditure to the agriculture sector.

- Policy should regulate the Facilitation of Public Private Partnerships between smallholder farmers and private sectors to establish and foster end-to-end value chain investment opportunities as well as efficient market.

- Policy should be addressed towards restructuring loan and credit availability to small-scale farmers via commercial banks and other agricultural finance institutions.

- Policies should be developed towards the inclusion of small-scale farmers in the broader formal supply chain network as this will encourage product standardization.

- Policies should be tailored towards restructuring the extension approach in engaging farmers as this is a key link to foster information flow between small-scale farmers, researchers and government just as it was in the 1960s when agriculture was still flourishing.

\section{Recommended policy implementation strategy}

- The government should embrace the use of formal or customarymeans toresolvelandadministrationissues.

- Stabilization of extension agents at strategic farm settlements for easy access by farmers, on-time information flow, on-farm training for efficient technology transfer, loan use monitoring, the recognition of target farmers, produce standard monitoring for easy access to a broader supply chain. Achievement of this is only possible when agriculture is given equal priority as oil.

- The government should also rehabilitate research institutes and academic institutions to function well in developing improved planting materials and pesticides that will enhance sustainability.

- The establishment of an efficient market is the key to production expansion. Therefore, the government should facilitate public-private partnerships to enhance end-to-end value chain investment and market support.

- Also, the structuring of farmers' centers in farming communities will help in aggregating small-scale produce (especially centers for the collection of milk from pastoralists) for a broader market supply chain. This should be facilitated by NGOs, the government and farmers.

\section{REFERENCES}

AGRA (Alliance for a Green Revolution in Africa) (2017). AGRA Nigeria Operational Plan. [Online] Available from https://agra.org/wp-content/uploads/2017/12/agra-nigeria-final.pdf

Ahungwa, G.T., Haruna, U., Abdusalam, R.Y. (2014). Trend Analysis of the Contribution of Agriculture to the 
Olugbire, O. O., Sunmbo, O., Olarewaju, T. O. (2021). Contribution of small-scale farming and local food supply to sustainable production and food security in Nigeria - A review. J. Agribus. Rural Dev., 1(59), 91-99. http://dx.doi.org/10.17306/J. JARD.2021.01390

GrossDomestic Product of Nigeria (1960-2012). J. Agric. Vet. Sci., 7(1). Retrieved from: http://iosrjournals.org/ iosr-javs/papers/vol7-issue1/Version-4/J07145055.pdf

Anderson, J., Marita, C., Musiime, D., Thiam, M. (2017). Understanding Their Demand for Financial, Agricultural, and Digital Solutions. Retrieved from http://documents.worldbank.org/curated/en/316661513583254475/pdf/122092WP-PUBLIC-Working-Paper-Survey-Segmentation-ofSmallholders-Nigeria-Oct-2017.pdf

Attah, A.W. (2012). Food Security in Nigeria: The Role of Peasant Farmers in Nigeria. Afr. Res. Rev., 6(4), 27. Retrieved from: https://www.researchgate.net/publication/272328247_Food_Security_in_Nigeria_The_Role of_Peasant_Farmers_in_Nigeria

David, M. (2011). Global Agricultural Information Network Report. Agric. Fin. Dev. Retrieved from: https://www.nigerianseminarsandtrainings.com/ articlespg/29-gain-report-nigeria--agricultural-finance-a

Eigege, J., Cooke, J. (2016). Tracing the Roots of Nigeria's AgriculturalDecline. Centre for Strategic and International Studies (CSIS). Retrieved from: https://csis-prod. s3.amazonaws.com/s3fs-public/publication/160505 Eigege_NigeriasAgriculturalDecline_Web.pdf

Ering, S.O., Otu, J.E., Archibong, E.P. (2014). Rural Development Policies in Nigeria: A Critical Appraisal. Int. J. Edu. Res., 2(9), 307-320. Retrieved from: http://www.ijern. com/journal/2014/September-2014/27.pdf

FAOSTAT (2020). FAO statistics - Nigerian Food security Portal. Rome: Food and Agriculture Organization.

FMARD (Federal Ministry of Agriculture \& Rural Development) (2001a). National Fadama Infrastructure Survey Report, Sheda-Abuja: World Bank/Projects Coordinating Unit.

FMARD (Federal Ministry of Agriculture \& Rural Development) (2001b). The New Nigerian Agricultural Policy. Retrieved from: https://www.g-fras.org/fr/2015-05-28-15$50-27 /$ australia-16.html?download $=310$ :the-new-nigerian-agricultural-policy-2001

FMARD (Federal Ministry of Agriculture \& Rural Development) (2016). Agricultural Policy for Nigeria. Abuja, Nigeria: FMARD.

Green, A.R. (2013). Agriculture is the future of Nigeria. Forbes. Retrieved from http://www. forbes.com/sites/skollworldforum/2013/08/08/ agriculture-is-the-future-of-nigeria/\#12cd8e 74bc9b

Ibeanu, O. (2008). Affluence and Affliction: The Niger Delta as a Critique ofPolitical Science in Nigeria. The TwentySeventh Inaugural Lecture ofUniversity ofNigeria, Nsukka. Retrieved from: http://www.unn.edu.ng/wp-content/ uploads/2015/09/27th-Inaugural-Lecture.pdf
Ibietan, J., (2011). Public Policy making Process: Agricultural and Rural Development policies in Nigeria (1960 to date). Int. J. Stud. Human. Retreved from http://eprints.covenantuniversity.edu.ng/3805/1/Dr.\%20Jide\%20Ibietan\%205. pdf

IFAD (International Fund for Agricultural Development) (2012). Scaling Up Note.Retrieved from: https://www. ifad.org/documents/10180/359371 f0-9c0c-4d07-a87b49df00c6e66d

Igbokwe, E.J. (1983). The effect of oil production on the agricultural economy of Nigeria, 1970-1980. Retrospective Theses and Dissertations. 16518. Retrieved from: https://lib.dr.iastate.edu/cgi/viewcontent.cgi?article= $17517 \&$ context $=$ rtd

Kolawole, S. (2009). Who wants to be a farmer? This Day (Backpage) Dec. 27.

Michael, J., Ibrahim, S.E. (2003). Agricultural Production and the EconomicDevelopment of Nigeria. J. Dev. Soc., 1(4), 71-81.

Nigeria Dairy Enterprise Initiative Final report (2007). Nigeria Dairy Enterprise Initiative Final report. USAID Grant EDH-G-00-03-00017-00 Final report. Retrieved from: http://pdf.usaid.gov/pdf_docs/Pdaci869.pdf

Onah, F.O. (2006). Managing Public Programmes and Projects. Nsukka: Great APExpress Publishers Ltd.

Oni, J.C. (2011). Tillage in Nigerian Agriculture. Retrieved from: http://iworx5.webxtra.net/ istroorg/download/Nigeria_conf_downloads/Key_Lead_Papers/Oni\%20KC. pdf

PWC (Price Water House Coopers). (2016). Transforming Nigeria's Agricultural Value Chain. A case study of the Cocoa and Dairy Industries. Retrieved from: https://www. pwc.com/ng/en/assets/pdf/transforming-nigeria-s-agricvalue-chain.pdf

Teal, F. (1983). The supply of Agricultural output in Nigeria. J. Dev. Stud., 19(1), 191-206. [Online] Available from https://www.tandfonline.com/doi/abs/10.1080/00220388 308421858? journalCode $=$ fjds 20

UNDP (United Nation Development Program). (2013). Roadmap Nigerian Agribusiness Supplier Development Program. Retrieved from: http://www.undp.org/content/dam/ nigeria/docs/IclusiveGrwth/UNDP_NG_RoadmapNigerianAgribussmaer2013.pdf

Wiggins, S. (2009). Can the Smallholder Model Deliver Poverty Reduction and Food Security For A Rapidly Growing Population in Africa? FAO Expert Meeting on Howto feed the World in 2050, 24-26, FAO, Rome. Retrieved from: https://opendocs.ids.ac.uk/opendocs/bitstream/handle/123456789/2338/FAC_Working\%20_Paper_08.pdf 
